\title{
Challenging Conceptual and Empirical Definition of e-Government toward Effective e-Governance
}

\author{
Angela Delli Paoli and Stefania Leone
}

\begin{abstract}
The impact of ICT on public service delivery has been debated in the form of e-government, e-democracy e-participation and e-governance. The article examines the way e-government is defined operationally in the international statistics such as the e-Government benchmark (European Commission) and the e-government survey (United Nations) in order to understand the concept measured. E-government, as defined empirically, seems not to consider government responsiveness to bottom-up forms of e-participation. Thus, judgments based on these statistics may be biased. Indeed, the analysis and evaluation of a citizen-driven system for local public service improvement - DecoroUrbano.org - which uses the internet to voice public services concerns or reporting issues, suggests that the unbalance highlighted in international statistics between a high level of supply (from governments) and a low level of demand (from citizens) may be inverted when considering these forms of distributed democracy.
\end{abstract}

Index Terms-Citizen-centric e-government, e-governance, distributed democracy, e-citizenship, e-participation, citizen sourcing.

\section{INTRODUCTION}

E-government is an umbrella concept which means many things to different people according to one's focus. The differences in defining e-government are not just semantic but reflect priorities in government strategies.

In its broader sense it can be defined as a system to improve organizational performance, processes' efficiency and the interaction between governments and citizens through Information and Communication Technologies (ICT) [1]-[3]. Thus, there are five main directions of e-government processes which express in different parties in communication: government to government, government to citizens, government to business [4], government to civil societal organizations and citizen to citizen [5]. The paper has a limited impact on government-to-government and government-to-business directions and especially leverages on the other directions. Within this perspective, e-government can be broadly defined as any way ICT is used to improve transactions between governments and their citizens [6].

Such a concept of e-government is strictly related to that of e-participation and e-democracy. In fact, services provision by public administrations (e-government) is meaningless without citizen usage of those services and citizen commitment on civic issues (e-participation). This is

Manuscript received October 20, 2013; revised December 21, 2013.

Angela Delli Paoli and Stefania Leone are with the Department of Political, Social and Communication Sciences of the University of Salerno, Fisciano (SA), 84084 Italy (e-mail: adellipaoli@unisa.it, sleone@unisa.it). recognized in the police agenda around the world and puts the concept of citizenship into the concept of e-government challenging procedures through which public governance is delivered and citizen-government relationships are based [7]. This leads to a cross-fertilization between e-government and e-governance by means of technology which significantly influence the shape and size of the citizen engagement in government and the possibility of engaging people in the agenda-setting process [8].

International statistics on e-government report a good position for Italy in the international e-government ranking but a still low level in service usage by citizens. By analyzing these data on these two sides of the same coin (e-government and e-participation), we can infer that progress in e-government have not been compensated by a substantial increase in the level of citizens up-take. However, these results are dependent on the conceptual and operational definition of e-government and e-participation. In other words, e-government measures seem to be grounded in a static representation of public service delivery which consists of a one-way street where government delivering and citizens receiving or on a two-way street centered on government perspective. On the other hand, e-participation measures do not account for more subtle and innovative forms of participations having a bottom-up nature (e.g., citizen sourcing). Thus, in this paper we analyze the way e-government and e-participation are defined operationally in the international statistics in order to discover which concept of e-government is measured and whether it includes forms of distributed democracy and citizen sourcing. We advance the hypothesis that such statistics do not account for an user-centric and e-governance perspective which would require also an analysis of government responsiveness to bottom-up forms of e-participation. Within this perspective, they cannot represent a point of reference to make judgments about potential changes going on in the relationship between citizen and government. This lack may produce an overrating in the judgment of e-government development and an underrating in the analysis of e-participation.

What is more, such a lack seems to make out of reach the user-focused government loudly declared a necessary step by most policy agendas. For instance, in the European e-Government Action Plan (2011-2015) [9] user empowerment is presented as one of the most important priorities and meant as a means to increase "the capacity of citizens $[\ldots]$ to be proactive in society through the use of new technological tools". The Commission recommends Member States for designing public services around citizens' needs, able to meet users' expectations, providing flexible and personalized ways of interaction with public administrations also via social networking and collaborative tools (such as 
those included in Web 2.0 technologies). Despite proclaiming citizen-centricity, e-government as represented in international data, seems to be a supply-driven concept supposed to provide administrations with opportunities of resetting their relationship with citizens and not vice versa [10]. In order to explain such a view, we analyze forms of distributed democracy and citizen sourcing which seem to indicate that there may be more than the available statistical data reveal. These forms are of paramount significance to our full understanding of citizen-government relationships within a citizen-centric perspective.

Particularly, we analyze an Italian web-based service designed to voice concerns or reporting public issues DecoroUrbano.org. Such a platform allows for direct feedback mechanisms: citizen may submit issues and local government officials are called to fix them (if they accept to participate in the project). Therefore, in the analysis of such a platform our research question is:

"Are local governments responsive to citizens concerns and request for information or problem resolution?"

Put in more general terms, we aim to investigate if the unbalance between service supply and service demand emerging from international statistics is confirmed.

The paper is therefore articulated into 4 sections. The second section presents findings on e-government and e-participation with a particular focus on Italy. The third section analyzes an Italian case of distributed democracy, an example of issue reporting website. The last section draws conclusion for e-government and provides suggestions for future developments.

\section{E-GOVERNMENT AND E-PARTICIPATION: MEASURES AND FINDINGS}

In the e-Government benchmark 2012 [11], [12] carried out by the European Commission e-government is defined with reference to service delivered in terms of public domains covered and resources available. The former is called life event experiences and is aimed to measure the set of services provided by public agencies. Here, the services delivery is assessed from the user perspective, defined on the basis of citizens' needs and aggregated into 4 categories: general; business, employment and education services. Mainly, it is a rearrangement of public services into categories of situations citizens would deal with.

The second is called Key ICT enablers and refers to the availability of government-issued electronic form of identification and authentication (e-Identity); the use of authenticated documents (e-Documents); the use of databases and archives to store and retrieve customer data (authentic sources); the safety of electronic means (e-Safe); the accessibility to multiple systems without multiple log-on (Single Sign On - SSO).

For each life event the online availability, usability, easy and speed of use of basic and extended services, the transparency of service delivery (estimate of time, service levels and receipt of notification), of personal data (possibility of accessing and modifying personal data stored) and of public administrations (publishing of relevant information), the availability of IT enablers is measured through mistery shopping, that is an evaluation method measuring services by simulating the user online experience and so acting as a prospective citizen [11].

Also the 2012 edition of the e-government survey carried out by United Nations [13] defines e-government in terms of services provided and builds an e-government development index (EGDI) as a composite measure derived from 3 indexes: online service index, telecommunication index and human capital index. The telecommunication and human capital indexes are referred to macro and contextual dimensions with the former measuring the communication infrastructure (in terms of internet users, fixed telephone lines, mobile subscribers, internet subscriptions, broadband facilities) and the latter measuring literacy (adult literacy rate and gross enrolment ratio). Thus, the measure related to e-government is the online service index. It is the result of an assessment of national central portal and e-service portals on the basis of several dimensions such as web content accessibility, usability, design, user-friendliness, the extent of content and features offered (such as archived information, downloadable databases and so on), the connected presence and interactive features (such as web comment forms, online consultation mechanisms, online decision-making procedures and so on), the accuracy and speed of consultation.

The analysis of results obtained both by European Commission and United Nations seems to confirm a relatively high maturity level of services for Italy.

In the e-Government benchmark 2012 Italy shows high levels of online availability and usability of public services. Considering the availability by life events, Italy presents the highest score of online availability for service simplifying business procedures. Apart from the online availability of education services, scores on both availability and usability are higher than the European average (see Fig. 1).

Also the 2012 edition of the e-government survey carried out by United Nation, seems to confirm such a trend by classifying Italy as one of the 25 emerging leaders in e-government development with an index value of 0,72 (see Table I).

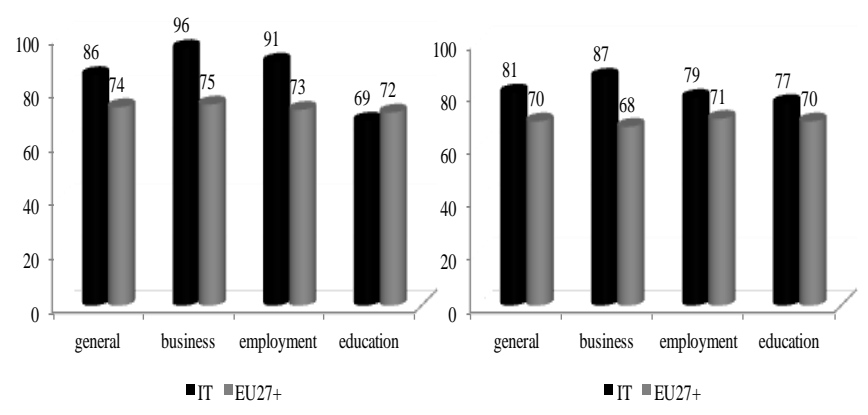

Source: European Commission, 2012

Fig. 1. Online availability and usability in Italy e-government.

Moreover, Italy is mentioned as a case of country supporting multichannel service delivery that is an integrated and coordinated system of public service provision by various communication means thanks to the project "Reti Amiche" (User-friendly networks). "Reti Amiche", supported by the Ministry for Public Administration and Innovation, is a platform which provides a point of access to 
services exiting in the private sector such as Post office, ATMs and so on.

TABLE I: TOP AND EMERGING LEADERS IN E-GOVERNMENT DEVELOPMENT

\begin{tabular}{|c|c|c|}
\hline Rank & Country & Index \\
\hline 1 & Republic of Korea & 0.9283 \\
\hline 2 & Netherlands & 0.9125 \\
\hline 3 & United Kingdom & 0.896 \\
\hline 4 & Denmark & 0.888 \\
\hline 5 & United States & 0.868 \\
\hline 6 & France & 0.863 \\
\hline 7 & Sweden & 0.859 \\
\hline 8 & Norway & 0.859 \\
\hline 9 & Finland & 0.850 \\
\hline 10 & Singapore & 0.847 \\
\hline 11 & Canada & 0.843 \\
\hline 12 & Australia & 0.839 \\
\hline 13 & New Zealand & 0.838 \\
\hline 14 & Liechtenstein & 0.826 \\
\hline 15 & Switzerland & 0.813 \\
\hline 16 & Israel & 0.810 \\
\hline 17 & Germany & 0.807 \\
\hline 18 & Japan & 0.801 \\
\hline 19 & Luxembourg & 0.801 \\
\hline 20 & Estonia & 0.798 \\
\hline 21 & Austria & 0.784 \\
\hline 22 & Iceland & 0.783 \\
\hline 23 & Spain & 0.777 \\
\hline 24 & Belgium & 0.771 \\
\hline 25 & Slovenia & 0.749 \\
\hline 26 & Monaco & 0.749 \\
\hline 27 & Russian Federation & 0.7345 \\
\hline 28 & United Arab Emirates & 0.734 \\
\hline 29 & Lithuania & 0.733 \\
\hline 30 & Croatia & 0.732 \\
\hline 31 & Hungary & 0.720 \\
\hline 32 & Italy & 0.719 \\
\hline 33 & Portugal & 0.716 \\
\hline 34 & Ireland & 0.714 \\
\hline 35 & Malta & 0.713 \\
\hline 36 & Bahrain & 0.694 \\
\hline 37 & Greece & 0.687 \\
\hline 38 & Kazakhstan & 0.684 \\
\hline 39 & Chile & 0.676 \\
\hline 40 & Malaysia & 0.670 \\
\hline 41 & Saudi Arabia & 0.665 \\
\hline 42 & Latvia & 0.660 \\
\hline 43 & Colombia & 0.657 \\
\hline 44 & Barbados & 0.656 \\
\hline 45 & Cyprus & 0.650 \\
\hline
\end{tabular}

Source: United Nations, 2012, 12

There are differences between the two surveys in defining e-participation which express in diverse units of analysis. In the European survey it is defined in terms of usage and the unit of analysis is citizens, whereas in the United Nations' survey it is defined in terms of e-services provided by governments which allow information, participation and active decision-making for citizens and the unit of analysis is government portals. The former measures the frequency of use of internet-based services as well as the overall level of satisfaction with these services. The latter splits the concept into three main components: e-consultation tools (online polls, online survey and feedback forms, listservs or newsgroups, weblogs, chat rooms or an IM feature and other interactive tools), $e$-decisions tools (online bulletin boards, discussion forums, petitions, voting, respond to citizen input and so on), online information tools.

Table II provides a synthesis of the operational definition of e-government and e-participation implemented by the European Commission and the United Nations.

The EU e-government survey finds that only 33\% of citizens are loyal users of e-government services.

A percentage is line with the European average (32\%). Reasons for not using them cover a wide range of motivations: from the lack of awareness of online services to the reluctance to internet means, the still existent digital divide, the difficulty in using and so on Table III.

However, the modest level of usage may also be due to an inadequate provision for e-participation tools.

This hypothesis is strengthen by the results of the UN survey which finds a very low level of e-participation tools in Italian e-government services attributing to Italy a score of $0 / 100$ in either the e-information and e-decision making components of the e-participation index and a score of $27 / 100$ to the e-consultation component.

TABLE II: THE OPERATIONAL DEFINITION OF E-GOVERNMENT

\begin{tabular}{|c|c|c|c|}
\hline Dimension & Survey & Operational definition & Technique \\
\hline \multirow[t]{2}{*}{ e-government } & $\begin{array}{l}\text { EU } \\
\text { e-gov } \\
\text { benchmark } \\
2012\end{array}$ & $\begin{array}{l}\text { User centricity } \\
\text { indicators: availability, } \\
\text { usability, ease of use, } \\
\text { speed of use of basic and } \\
\text { extended services. } \\
\text { Transparency indicators: } \\
\text { transparency of service } \\
\text { delivery, public } \\
\text { organizations, personal } \\
\text { data. } \\
\text { Preconditions indicators: } \\
\text { availability of e-ID, } \\
\text { e-Documents, Authentic } \\
\text { Sources, e-Safe, SSO. }\end{array}$ & $\begin{array}{l}\text { Mistery } \\
\text { shopping }\end{array}$ \\
\hline & $\begin{array}{l}\text { UN } \\
\text { e-gov survey } \\
2012\end{array}$ & $\begin{array}{l}\text { Online service index: } \\
\text { content accessibility, } \\
\text { usability, design, } \\
\text { user-friendliness, extent } \\
\text { of content, interactive } \\
\text { features and connected } \\
\text { presence, accuracy and } \\
\text { speed of consultation. }\end{array}$ & $\begin{array}{l}\text { Researchers' } \\
\text { assessment }\end{array}$ \\
\hline \multirow{2}{*}{ e-participation } & $\begin{array}{l}\text { EU } \\
\text { e-gov } \\
\text { benchmark } \\
2012\end{array}$ & $\begin{array}{l}\text { Usage, user satisfaction } \\
\text { and sentiment metrics }\end{array}$ & $\begin{array}{l}\text { User survey } \\
\text { Mistery } \\
\text { shopping }\end{array}$ \\
\hline & $\begin{array}{l}\text { UN } \\
\text { e-gov survey } \\
2012\end{array}$ & $\begin{array}{l}\text { e-consultation, e-decision } \\
\text { making, information } \\
\text { tools provided }\end{array}$ & $\begin{array}{l}\text { Researchers' } \\
\text { assessment }\end{array}$ \\
\hline
\end{tabular}

Source: Authors' own elaboration

Indeed, the low usage of web 2.0 tools used in e-decision making seem to be a worldwide trend, as shown in Fig. 2.

By looking exclusively at the low uptake of internet services, we could wrongly infer that there is a lack of interest in such services.

In other words, what seems to be missing in these findings is a measure of the level of governments' responsiveness and 
interactivity, a dimension which seems to be very strictly related to e-government concept, especially to mature e-government initiatives? If the United Nations measure e-participation in terms of interactive tools provided by governments, they still do not consider bottom-up e-participation tools not deriving from governmental initiatives and the level of responsiveness of government to citizens requests. In these cases, the definition of e-government is narrowed to the provision of electronic public services, not including democratic participatory tasks and activities. This, as hypothesized by some authors [14] may also be due to an explicit distinction between policy aimed to enhance electronic public service provision (e-government) and policy aimed to increase online democratic participation (e-democracy or e-participation). This lack can be also found in the studies on the models of e-government development where the importance of activating information flows from citizens to government seems not to be recognized.

TABLE III: REASONS FOR NOT USING E-GOVERNMENT SERVICES

\begin{tabular}{|l|c|}
\hline \multicolumn{1}{|c|}{ Reasons } & Response \% \\
\hline Not aware of existence relevant websites/online services & 27 \\
\hline Preferred to have personal contact & 24 \\
\hline $\begin{array}{l}\text { Expected to have things done more easily by using other } \\
\text { channels }\end{array}$ & 12 \\
\hline Concerns about protection and security of personal data & 6 \\
\hline $\begin{array}{l}\text { No skills/knowledge to get what I wanted/needed via the } \\
\text { Internet }\end{array}$ & 11 \\
\hline Could not find or access the information or services & 38 \\
\hline $\begin{array}{l}\text { Services will require personal visits/paper submission } \\
\text { anyway }\end{array}$ & 4 \\
\hline Abandoned the service because too difficult to use & 5 \\
\hline Abandoned the service because of technical failures & 9 \\
\hline Did not expect to save time by using the Internet & 8 \\
\hline Other reasons & Source: European Commission, 2012 \\
\hline
\end{tabular}

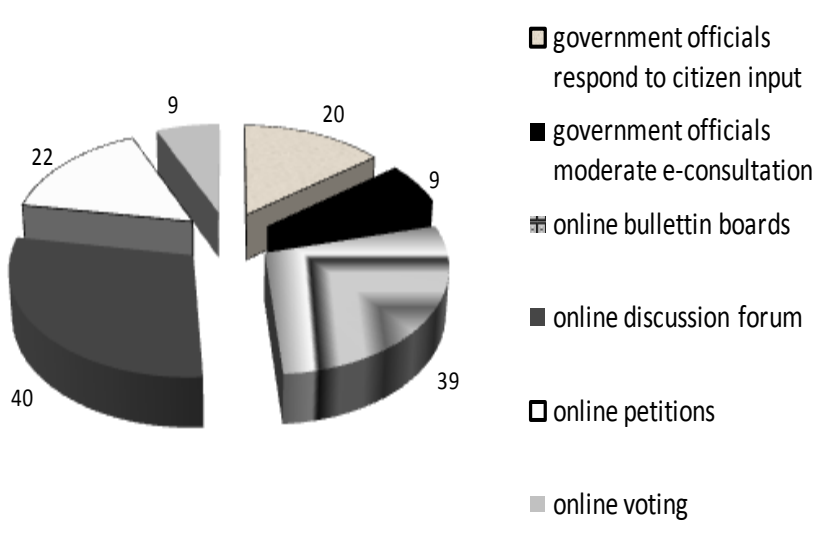

Source: United Nations, 2012, 47

Fig. 2. Usage of web 2.0 tools (\% of countries).

The studies on the models of e-government development are premised on the idea that organizations pass through the notional stages of maturity and distinguish different stages in e-government evolution characterizing the steps of a supposed continuous process. Two streams of research seem to emerge from the literature on e-government development. The former focusing on an internal perspective stressing the importance of integration across functions as e-government develops and the latter focusing on an external perspective which views the progress as directly linked to an improvement of contents and interactivity.

As to the former stream, Layne and Lee [15] detect four stages explained in terms of increased integration:

- cataloguing;

- transaction;

- vertical integration;

- involved complexity

Andersen and Henriksen [16] extended such a model by focusing less on technological capacity and more on activities and a customer centric approach. Still, a study on benchmarking e-government carried out by the United Nations and The American Society for Public Administration [17] proposed a five-stage model of development articulated in emerging, enhanced, interactive, transactional and seamless stages where the outcome is the integration of electronic services across government agencies.

Gottschalk [18] defined a maturity model based on the concept of interoperability that is the capability of different units and agencies of working together by integrating information and business processes. He detected five levels of interoperability in digital government: system, process, knowledge, value and goal interoperability.

As to the latter stream, Moon [19] identifies five stages where the first one is characterized by simple information dissemination and the last one by interactive tools directly provided by governmental web sites (online voting, forums, opinion surveys and so on). Moreover, West [3] distinguishes four stages of transformation:

- the billboard stage where e-government consists of static information display;

- the partial-service-delivery stage where online services are provided but in limited areas;

- the portal stage where a one-stop portal is provided integrating online services;

- the interactive democracy stage where interactive features aimed to boost democratic responsiveness and leadership accountability are provided.

Within this perspective, an interesting model taking into account user needs and the role of citizen-government information flow is that proposed by Lee and Kwak [20] called "open government maturity model". The model is conceived in an incremental way and is articulated into:

- initial condition where limited information are provided;

- data transparency focusing on publishing relevant data to increase transparency;

- open participation where governments adopt social media in an expressive way, that is to collect and receive public's ideas and opinions;

- open collaboration where governments adopt social media in a collaborative way for complex tasks and with the aim to co-create specific outputs;

- ubiquitous engagement which requires an integration of services provided and an extension of devices including 
smart phones.

Obviously, these are oversimplifications of reality useful only for classificatory aims.

Apart from these different typologies and diverse ways of calling the stages, the evolution of e-government initiatives as described by these authors seems to be based on widening e-government initiatives leveraging on three lines of development:

- the organizational efficiency;

- the enrichment of content provided;

- the improvement of interactivity.

Indeed, neither stream highlight the need for governments in a highly mature stage of e-government to be responsive to non-governmental initiatives. Thus, we propose a model of e-government development which takes into account such a need. The model, leveraging on the stages proposed by Lee and Kwak, focuses on the type of citizen-government relationship and on the channels needed to such a relationship and is provided in tab. IV.

In what we have called an emerging stage, government plays an almost exclusively informative role and activates a one-way flow of information with citizens receiving information on public policy, governance, laws, regulations and so on, but not being able to reply. In this stage, a static website is used to communicate to citizens.

In the developing stage governments adopt a service orientation perspective undergoing simple two-way interactions by providing e-service designed to strengthen the relationship with citizens (e.g. downloadable forms, requesting and receiving inputs on government policies, etc.) These initiatives are defined go-driven customer centricity because the agenda of the two-way flow of communication is set by governments and no possibility of intervention on this is prescribed for citizens. Within this perspective, e-government can be defined as the usage of IT to improve administrative efficiency. In this stage, a dynamic website is implemented providing interaction mechanisms. The international statistics analyzed seem to measure this type of e-government. Probably, Italy is so undergoing this stage of e-government development.

The last stage, innovative stage, requires an integrated communication where governments and citizens are both senders and receivers. In this case, governments use both institutional means (government websites) and integrated applications and interactive tools to answer to citizens concerns and requests. This stage is similar to those of open collaboration and ubiquitous engagement proposed in Lee and Kwak's model but includes also government responsiveness to non-governmental initiatives. This stage represents a paradigm shift in citizen engagements and empowerment and it synthesizes the meaning of the concept of responsiveness. It gives rise to increased transparency and accountability of government processes and changes the relationship between government and citizens creating new spaces for citizens to participate in governance.

In so doing, it realizes e-governance assumptions by providing citizens with the ability to choose the way of interacting with governments and by harnessing their democratic potential.

Indeed, the experience of other States (e.g. United
Kingdom or United States) demonstrates that when citizens are given e-services which allow for bottom-up participation and when responsiveness is assured, the usage levels increase.

In Italy the lack of such governmental e-participation tools, has lead to private projects of e-participation services such as those analyzed in Section III.

TABLE IV: AN USER-CENTRIC E-GOVERNMENT DEVELOPMENT MODEL

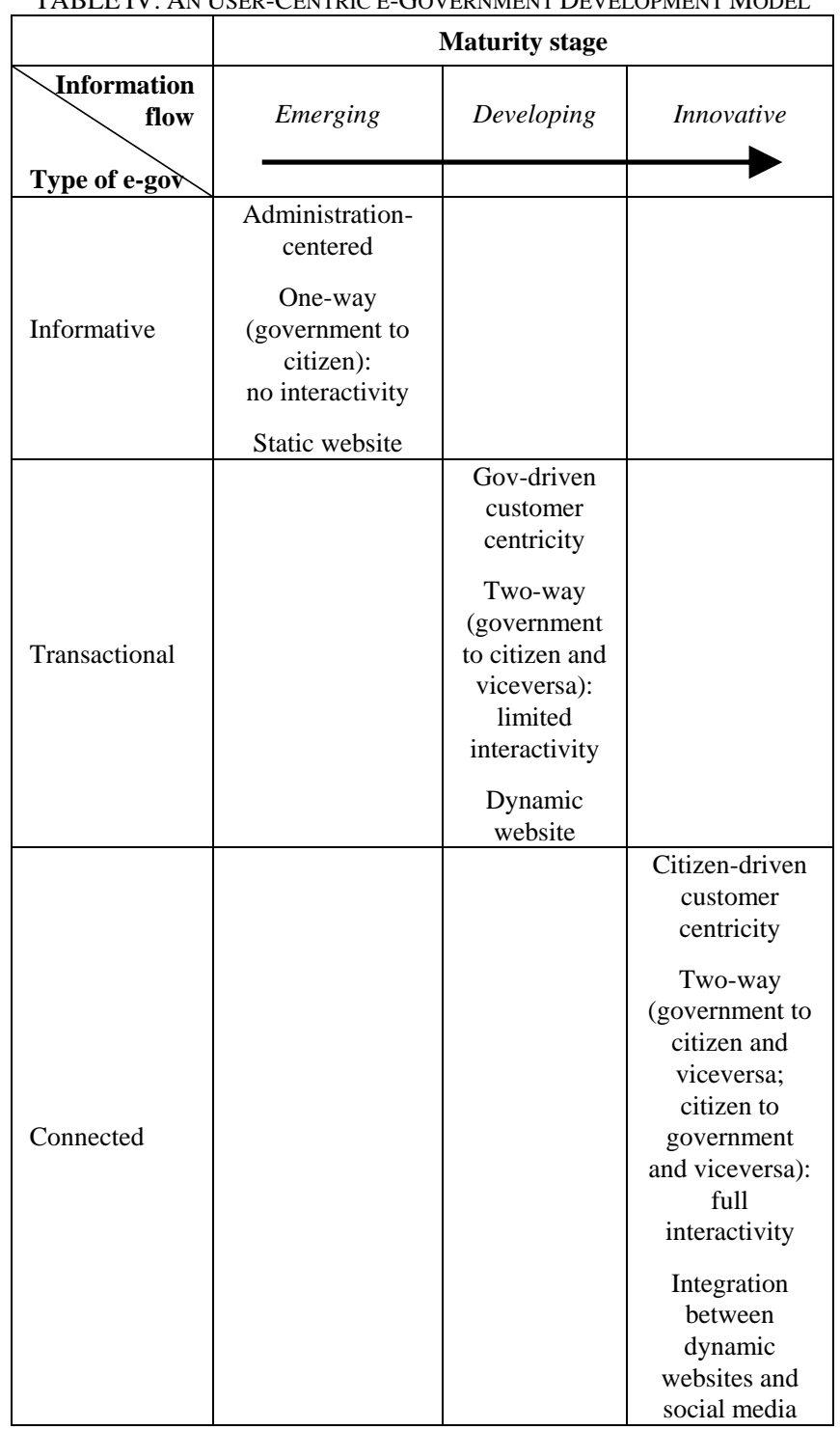

Source: Authors' own elaboration

\section{FORMS OF DISTRIBUTED DEMOCRACY: THE CASE OF DECOROURBANO.ORG (WEDU)}

The bottom-up e-participation tools abovementioned are forms of distributed democracy allowing:

- a direct connection between citizens and governments;

- the use of channels directly chosen by citizens, a citizen-driven online submission system and an user-generated problem reports;

- an active responsiveness cycle.

This forms of distributed democracy can be considered a type of ICT-enabled co-production of information deriving from "citizen sourcing" initiatives where the information flow is directed by citizens: "in citizen sourcing public helps government be more responsive and effective. Government 
holds primary responsibility, but citizens influence direction and outcomes, improve the government's situational awareness, and may even help execute government services on a day-to-day basis" [21]. They rely on social media which allow for user-generated content and many-to-may forms of interaction and descend from the embracement of the use of social media for government purposes. There are lots of international examples of such initiatives. In tab. V we report a non-exhaustive list of such initiatives. These initiatives are built on the issue of public accountability [22] and can be considered a way to see exactly where power and responsibility lie. Moreover, they make public the "complaints mechanism" amplifying citizens' voice, transferring power from the council to the hands of the citizen and encouraging public debate [23]. Such projects have been also defined as "geo-citizen framework" to indicate an user-friendly environment which fully integrates web mapping tools and social media [24]. Some of these initiatives have been previously studied as forms of distributed democracy. For instance FixMystreet has been analyzed by King and Brown [25], ClickFlick by Mergel [26], IRIS by Alfano [27]. The tools abovementioned are in some cases directly provided by local governments which use them to let citizens inform them about problems.

Focusing on Italy, an example of distributed democracy is represented by the website DecoroUrbano.org (WEDU) (http://www.decorourbano.org/). It is a web-based service designed to allow citizens to report issues. These include environmental issues (disposal, pollution, environmental degradation, etc.), vandalism, broken infrastructure, road safety and disrupted streets (uneven road surface, graffiti, fly tipping, broken paving slabs, or street lighting, etc.), illegal billposting, transportation infrastructure and so on. Governments can agree or disagree to enter the platform. If they accept, they contextually undertake the responsibility toward submitted issues, they need to assign them a work order number and they can change the status of repair: from open, in progress, to fixed. The platform has been launched by a small Italian start-up, Mioras Lab S.r.l., in 2011. The service is opensource and opendata, that is it is free to use and no fees are charged to local authorities.

It is integrated into the social networking services Twitter and Facebook and is built on an intuitive map-based interface, an easy-to-use geotagging encoding (GeoRSS, e.g. a location enabled RSS feed). Citizens can report problems on an online map showing the location where the problem is, they can also take and upload photographs of the problem they want to signal. The maps on the website are referred to the whole Italy.

In order to evaluate the effectiveness of DecoroUrbano.org to date and its future potentials as well as to answer to our research question asking if also in these initiatives of distributed democracy the commitment of governments is not compensated by citizens interest, we analyze the flow of information on such a platform.

Particularly, we analyze the portal usage in terms of participation of both citizens and public administrations and type of issue reported and the portal efficiency in terms of fixed and still open issues (see tab. VI). (Data are drawn from a thesis in Theory and Analysis of Social Institutions by
Alessio Napolitano supervised by the authors).

TABLE V: SOME CITIZEN SOURCING INTERNATIONAL INITIATIVES

\begin{tabular}{|l|l|l|}
\hline Initiative & Area & URL \\
\hline SeeClickFix & US & http://it.seeclickfix.com/ \\
\hline Park Scan & San Francisco & http://www.parkscan.org/ \\
\hline Crime reports & US \& Canada & https://www.crimereports.com/ \\
\hline SpotCrime & US & http://spotcrime.com/ \\
\hline City sourced & US & $\begin{array}{l}\text { http://www.citysourced.com/de } \\
\text { fault.aspx }\end{array}$ \\
\hline FixMytransport & UK & $\begin{array}{l}\text { http://www.fixmytransport.com } \\
\text { / }\end{array}$ \\
\hline Fixmystreet & UK & http://www.fixmystreet.com/ \\
\hline Iris & municipality (IT) & http://iris.comune.venezia.it/ \\
\hline AidyourCity & IT & http://www.aidyourcity.com/ \\
\hline DecoroUrbano & IT & http://www.decorourbano.org/ \\
\hline
\end{tabular}

Source: Authors' own elaboration

Starting from the analysis of citizens' side, data show clearly that the platform is being used as a means for citizens to report problems to the council (see Table VII). The most reported problems concern illegal waste and disrupted streets. As we can see from the table, the number of issue reported is quite high (12969). The figure indicates a relative high level of citizens' participation.

Turning to the analysis of government side, the usage of the platform seems to be quite low ( $1 \%$ of local authorities can be classified as active PAs, that is as local governments actively participating in the platform and taking care of answering to reports).

Findings differ by location: the south of Italy shows the higher level of participation by local governments whereas the north of Italy the lowest one Table VIII.

Participation of local authorities in the platform does not mean effective participation. The efficiency of government participation is referred to its capability of fixing issues reported measured as a ratio between the number of issue fixed and the number of issue reported (efficiency index).

TABLE VI: THE OPERATIONAL DEFINITION

\begin{tabular}{|l|l|}
\hline Concept & Indicators \\
\hline \multirow{4}{*}{$\begin{array}{l}\text { Portal } \\
\text { usage }\end{array}$} & Number of issue reported \\
\cline { 2 - 2 } & $\begin{array}{l}\text { Number of Public administrations adopting } \\
\text { DecoroUrbano.org }\end{array}$ \\
\cline { 2 - 2 } & Types of issue reported (analysis of posting) \\
\hline \multirow{4}{*}{$\begin{array}{l}\text { Portal } \\
\text { efficiency }\end{array}$} & $\begin{array}{l}\text { Number of issue fixed by location } \\
\text { reported) }\end{array}$ \\
\cline { 2 - 2 } & Number of issue reported waiting for an answer \\
\hline
\end{tabular}

Source: Authors' own elaboration

From this point of view, also the efficiency of local authorities seem to be unsatisfying with a percentage of resolution of $26 \%$ in Italy and a better performance of the south $(40 \%)$ (see Table IX). This is very risky as it does not allow to activate a real responsiveness cycle and a bi-directional relationships with citizens. 
By looking at still open issue, we can obtain another indicator of Public administrations' efficiency (see Table X).

The percentage of still open issues related to inactive local authorities indicates the presence of unsatisfied demands from citizens and unheard complaints.

To conclude, the analysis of Decorourbano.org usage seems to invert the findings of international statistics above presented (see Section II) because it seems to reverse the unbalance between government supply and citizen demand. Here, citizens' demand seems to exceed government responsiveness. The platform seems not to be used as a channel of information exchange by governments and a feedback mechanism between citizens and local governments.

TABLE VII: TYPE OF ISSUE REPORTED BY AREA (APRIL 2013)

\begin{tabular}{|l|l|l|l|r|}
\hline Issue reported & South & Center & North & Italy \\
\hline Illegal waste & 1818 & 1811 & 907 & 4536 \\
\hline Vandalism & 745 & 1341 & 528 & 2614 \\
\hline Disrupted streets & 1168 & 1012 & 609 & 2789 \\
\hline Environmental degradation & 310 & 415 & 206 & 931 \\
\hline Signpost & 226 & 426 & 208 & 860 \\
\hline Illegal billposting Total & 4483 & 5945 & 2541 & $\mathbf{1 2 9 6 9}$ \\
\hline
\end{tabular}

Source: DecoroUrbano.org internal statistics

TABLE VIII: THE PlatForm USAGE BY LOCAL AUTHORITIES By AREA

\begin{tabular}{|l|c|c|c|}
\hline Area & $\begin{array}{c}\mathbf{N}^{\circ} \text { of PA } \\
\text { participating }\end{array}$ & $\begin{array}{c}\text { Total number } \\
\text { of PA }\end{array}$ & $\begin{array}{c}\text { Percentage } \\
\text { of usage }\end{array}$ \\
\hline South of Italy & 36 & 2252 & $10.4 \%$ \\
\hline Center of Italy & 23 & 1301 & $7.8 \%$ \\
\hline North of Italy & 23 & 4541 & $0.5 \%$ \\
\hline Total Italy & 82 & 8094 & $1 \%$ \\
\hline
\end{tabular}

Source: DecoroUrbano.org internal statistics

TABLE IX: EFFICIENCY INDEX

\begin{tabular}{|l|c|c|c|c|c|}
\hline Area & $\begin{array}{c}\mathbf{N}^{\circ} \text { of } \\
\text { active } \\
\text { PA }\end{array}$ & $\begin{array}{c}\mathbf{N}^{\circ} \text { of } \\
\text { issue } \\
\text { reported }\end{array}$ & $\begin{array}{c}\mathbf{N}^{\circ} \text { of } \\
\text { issue } \\
\text { fixed }\end{array}$ & $\begin{array}{c}\text { Issue fixed } \\
\text { by PA } \\
\text { (mean) }\end{array}$ & $\begin{array}{c}\text { Efficiency } \\
\text { index }\end{array}$ \\
\hline South & 36 & 1707 & 690 & 19 & $40 \%$ \\
\hline Center & 23 & 4879 & 1056 & 46 & $21 \%$ \\
\hline North & 23 & 946 & 248 & 11 & $26 \%$ \\
\hline Total & 82 & 7532 & 1994 & 24 & $26 \%$ \\
\hline
\end{tabular}

Source: DecoroUrbano.org internal statistics

TABLE X: INEFFICIENCY INDEX

\begin{tabular}{|l|c|c|c|}
\hline Area & $\begin{array}{l}\text { Total issues } \\
\text { reported }\end{array}$ & $\begin{array}{l}\text { Issue concerning } \\
\text { inactive PA }\end{array}$ & $\begin{array}{l}\text { \% of still } \\
\text { open issue }\end{array}$ \\
\hline South & 4483 & 3524 & $79 \%$ \\
\hline Center & 5945 & 1160 & $20 \%$ \\
\hline North & 2541 & 2277 & $90 \%$ \\
\hline Total & 12969 & 6961 & $54 \%$ \\
\hline
\end{tabular}

Source: DecoroUrbano.org internal statistics

This is confirmed by the high number of governmental non-adopters and unresolved issues.

\section{DISCUSSION AND CONCLUSION}

Although very easy to use, the impact of decororbano.org is somewhat limited. To achieve solutions that will endure, both parties need to be active and committed participants.

The analysis of a platform of distributed democracy and citizen sourcing reveals a gap in e-government service and the presence of an unsatisfied demand coming from citizens. Obviously, in order to generalize such result a more in depth analysis will be needed. Such an analysis should extend the evaluation to:

- all other portals of citizen sourcing operating in Italy (such as aidyourcity, for instance);

- all other governmental initiatives of citizen sourcing directly provided by public administrations.

Our analysis shows that, most of the time, government does no send a response back to citizens and it is oftentimes unclear if an issue has been take care of or is still open. This disconnect - between citizen needs and government action results in a one-directional reporting with no feedback mechanisms.

It seems to suggest that perhaps the next stage in the journey toward ICT-enabled citizen-centric public service what we have called the innovative stage of e-government requires that governments approach new form of e-participation. This implies a "social media-based real time collaborative government model" which asks for a transformation from e-government to open-government [20].

A social media- based government has been defined in different terms: crowdsourcing, citizen sourcing [28], collaborative government [29], wiki government [30], open government, do-it-yourself government [31], government as a platform [8].

If implemented properly, such a model will help to develop and consolidate principles of good governance based on responsiveness and accountability.

Obviously, this implies that citizens have to be viewed as a co-production partner, not merely as a passive customer of government information and services. This may force a re-interpretation of the role of government and of its responsibility toward citizens and demonstrates that effective e-government cannot be sustained without strengthening e-governance. As O’Reilly [8] emphasizes:

"[...] government 2.0 is not a new kind of government; it is government stripped down to its core, rediscovered and remained as it for the first time. And in that reimagining, this is the idea that becomes clear: government is, at bottom, a mechanism for collective action. We band together, make laws, pay taxes, and build the institutions of government to manage problems that are too large for us individually and whose solution is in our common interest. Government 2.0, then, is the use of technology - especially the collaborative technologies at the heart of web 2.0 - to better solve collective problems at a city, state, national, and international level. [...] Citizens are empowered to spark the innovation that will result in an improved approach to governance. In this model, government is a convener and an enabler rather than the first mover of civic action".

If these initiatives remain disconnected from institutional processes not taking actions based on citizens' input and not 
giving rise to robust collaboration between citizens and governments, they remain limited in scope.

Failure in social media engagement may have serious consequences for government reputation, may produce declining rates of trust in government and, at the very worst, a crisis of legitimacy.

It is undeniable that there seems to be many challenges in the adoption of such an innovative e-government model. Although social media initiatives are not so expensive - often these tools are free of charge - they require significant investments in time, network infrastructure and human resources. In fact, they need dedicated personnel, a shift in the organizational culture still based on hierarchical, top-down and siloed organizations, effective management processes and governance structures at the basis of the capability of managing multiple communication channels [20].

However, the outdated theory and method of participatory democracy and e-government which drives the design of government institutions may cause a further slowness to capitalize on this social capital.

The point is that in order to evaluate e-government development within an user-centric perspective the analysis cannot be limited to an evaluation of the effectiveness of public web site but an essential element is to analyze the effectiveness of government responsiveness to citizens concerns not only reported on governmental web sites. Measuring the breath (in terms of number $f$ services offered) and the depth of services provided may be not enough.

Even though e-government has a huge potential to contribute to transforming the relationship between citizens and governments, it is being developed according to a narrow and unidirectional conception of services.

At present, after more than a decade of e-government, substantial investments and a strong legislative support, the issue is no longer whether government is online, but in what forms, channels and to what extent.

\section{REFERENCES}

[1] Accenture, Institute for Health \& Public Service Value, From e-Government to e-Governance Using New Technologies to Strengthen Relationships with Citizens, 2009.

[2] P. Gottschalk, "Maturity levels for interoperability in digital government," Government Information Quarterly, vol. 26, pp. 75-81, 2009.

[3] D. M. West, "E-government transformation of service delivery and citizen attitudes," Public Administration Review, vol. 64, no. 1, pp. 15-27, Jan.-Feb. 2004.

[4] M. M. Brown and J. L. Brudney, "Achieving advanced electronic government services: An examination of obstacles and implications from an international perspective," presented at the National Public Management Research Conference, Bloomington, IN, October 2001.

[5] M. Yildiz, "E-government research: Reviewing the literature, limitations, and ways forward," Government Information Quarterly, vol. 24, pp. 646-665, March 2007.

[6] M. J. Moon, "The evolution of e-government among municipalities: rhetoric or reality?" Public Administration Review, vol. 62, no. 4, pp. 425, July/August 2002.

[7] M. Lips, "E-government under construction. Challenging traditional conceptions of citizenship," in E-Government in Europe. Re-Booting the State, P. G. Nixon, V. N. Koutrakou, Eds. New York: Routledge, 2007 , ch. 3 , pp. 34 .
[8] T. O'Reilly, Government as a Platform, in D. Lathrop, and L. Ruma (eds.), "Open government: collaboration, transparency, and participation in practice,” O'Reilly Media, 2010, ch. 2, pp. 12-13.

[9] European Commission, Communication from the commission to the European Parliament, the Council, the European Economic and Social Committee and the Committee of the Regions, COM 82010) 743, The European e-Government Action Plan 2011-2015, Harnessing ICT to Promote Smart, Sustainable and Innovative Government.

[10] M. Lips, "E-government under construction. Challenging traditional conceptions of citizenship," in E-Government in Europe. Re-Booting the State, P. G. Nixon, V. N. Koutrakou, Eds. New York: Routledge, 2007, ch. 3, pp. 37.

[11] European Commission, "E-government benchmark framework 2012-2015," method paper, final report, 2012.

[12] European Commission, Directorate-General of Communication networks, Content \& technology, Public Service Online, Digital by Default or by Detour, Assessing User Centric e-Government Performance in Europe-e-Government Benchmark 2012, insight report, 2013.

[13] United Nations, Department of economic and social affairs, E-government Survey 2012, e-Government for the People, 2012.

[14] M. Lips, "E-government under construction. Challenging traditional conceptions of citizenship," in E-Government in Europe. Re-Booting the State, P. G. Nixon, V. N. Koutrakou, Eds. New York: Routledge, 2007 , ch. 3, pp. 40.

[15] K. Layne and J. Lee, "Developing fully functional e-government: A four-stage model," Government Information Quarterly, vol. 18, no. 2, pp. 122-136, summer 2001

[16] K. V. Andersen and H. Z. Henriksen, "E-government maturity models: Extension of the Layne and Lee model," Government Information Quarterly, vol. 23, pp. 236-248, 2006.

[17] United Nations, American Society for Public Administration (ASPA), Benchmarking e-Government: A Global Perspective, New York: U.N. Publications, 2002.

[18] P. Gottschalk, "Maturity levels for interoperability in digital government," Government Information Quarterly, vol. 26, pp. 75-81, 2009.

[19] M. J. Moon, "The evolution of e-government among municipalities: rhetoric or reality?" Public Administration Review, vol. 62, no. 4, pp. 426-427, July/August 2002.

[20] G. Lee and Y. H. Kwak, “An open government maturity model for social media-based public engagement," Government Information Quarterly, vol. 29, pp. 492-503, 2012.

[21] D. Linders, "From e-government to we-government: Defining a typology for citizen coproduction in the age of social media," Government Information Quarterly, vol. 29, pp. 446-454, 2012.

[22] H. Sullivan, "New forms of local accountability: coming to terms with 'many hands'?" Policy and Politics, vol. 31, no. 3, pp. 353-369, July 2003.

[23] S. F. King and P. Brown, "Fix my street or else: using the internet to voice local public service concerns," presented at ICEGOV2007, Macao, December 10-13 2007, pp. 78.

[24] R. Resl, A. Eirzinger, and K. Atzmanstorfer. (2012). Platform for Collaborative Problem Solving within the Citizen's Spatial Cont ext the Geo-Citizen framework. [Online]. Available: http://proceedings.esri.com/library/userconf/proc12/papers/857_226.p df

[25] S. F. King and P. Brown, "Fix my street or else: using the internet to voice local public service concerns," presented at ICEGOV2007, Macao, December 10-13 2007, p. 78.

[26] I. Mergel. (2012). Distributed democracy: See Click Fix com Crowdsourced issue reporting. [Online]. Available: http://ssrn.com/abstract=1992968

[27] G. Alfano, "Adapting bureaucracy to the internet: the case of Venice Local Government," Journal Information Polity, vol. 16, no. 1, January 2011.

[28] L. Torres, "Citizen sourcing in the public interest," Knowledge Management for Development Journal, vol. 3, no. 1, pp. 134-145, 2007.

[29] M. Guire, "Collaborative public management: Assessing what we know and how we know it," Public Administration Review, vol. 66, pp. 33-43, 2006.

[30] B. Noveck, Wiki Government: How Technology Can Make Government Better, Democracy Stronger, and Citizens More Powerful, Washington, DC: Brookings Institutions Press, 2009.

[31] P. Dunleavy and H. Z. Margetts, "The second wave of digital era governance," presented at APSA 2010 Annual Meeting Papers, 2010. 


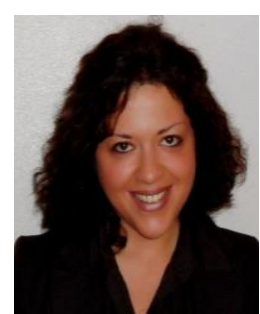

Angela Delli Paoli is a Ph.D. and postdoctoral research fellow in sociology, she was born in Caserta (Italy), February 11, 1982. She received her $\mathrm{Ph} . \mathrm{D}$. in Entrepreneurship and Innovation in 2010 from the Second University of Naples (Italy). She graduated cum laude in 2005 with a master degree in Communication and a thesis in Social Research Methods at the University of Salerno (Italy). She developed expertise in the methodologies and technologies of social research through teaching experience, research on field and advanced training. She attended on a regular basis courses of advanced quantitative and qualitative methods. Author of monographic studies (such as Social capital as the substantial concept of social network research. A methodology for a systematic literature review, Lambert Academic Publishing, 2012), essays and articles published in national and international journals, she has also teaching experience - prevalently in Social Research Methods and Public Communication - at both undergraduate and postgraduate levels. Prof. Delli Paoli was visiting researcher at the London Business School (UK) in 2008 and has been holding a Postdoctoral Research Fellow position at the University of Salerno (Italy) since 2010. She is also in charge of Research Activities at the Observatory for Communication and Participation of Youth Cultures, a research centre on youth which is established within the University of Salerno by the Youth Department of the Campania Region. Her current research interests include social research methods, public communication, public policy evaluation, youth cultures, social media.

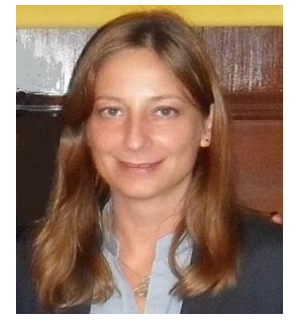

Stefania Leone is a Ph.D. and tenured researcher and assistant professor in sociology, she was born in Rome (Italy), March 11, 1973. She received her Ph.D. in Communication (sociological area) in 2005 from the University of Salerno (Italy) with a thesis in public communication and institutional organizations. She was research fellow at Department of Communication in the area of digital communication for private and public organizations. She teaches theory and analysis of public communication (undergraduate degree programme) and theory and analysis of social institutions (master degree programme). Her research areas cover the fields of sociology, public policies, social research methods and communication. Particularly, she is interested in the study of social interactions among public and private actors, social and governmental institutions and youth cultures within a micro and a macro sociological perspective. She coordinates the Observatory for Communication and Participation of Youth Cultures, a research centre on youth which is established within the University of Salerno by the Youth Department of the Campania Region. he is author of monographic studies, essays and articles; among her latest works: Leone S. (eds.) Nuove generazioni e ricerca sociale per le politiche giovanili (FrancoAngeli, Milano, 2012). 